\title{
Selection of the best lecturers using the Simple Additive Weighting method
}

\author{
Achmad Noeman', Wowon Priatna², Abrar Hiswara \\ Department of Informatics, Faculty of Computer Science, \\ Universitas Bhayangkara Jakarta Raya Jalan Raya Perjuangan Bekasi Utara, West Java, Indonesia ${ }^{1,2,3}$
}

\begin{abstract}
In the process of determining the best lecturer by students, there are several criteria, including in terms of explaining the material, teaching methods, which make it easier for students to follow their courses. To assist in the selection process for someone to become the best lecturer for students, a decision support system is needed using Fuzzy Multiple Addictive Decision Making (FMADM). This study uses the SAW (Simple Addictive Weighted) method based on predetermined criteria. The SAW method can determine the selection of the best lecturer based on predetermined criteria for students, as well as looking for the weight value of each attribute to get the best lecturer.
\end{abstract}

Keywords: Fuzzy Multiple Addictive Decision Making, SAW Method, Decision Support System, criteria for the best lecturers

\section{INTRODUCTION}

lecturers who are liked by students are a must in creating a comfortable and smooth learning process in the classroom that makes students enthusiastic about participating in the lecture process so that the learning process is more effective. Lecturers are professional educators and scientists with the main task of transforming and developing knowledge[1].

Bhayangkara Jakarta Raya University is a higher education institution that seeks to improve the quality of the learning process so that it can produce graduates who have competencies in their fields. Based on the Law of Republic of Indonesia No. 14 of 2005 concerning Teachers and Lecturers, that lecturers are entitled to promotions and awards according to with his academic performance[2].

With the appreciation of lecturers it can increase motivation which will have an impact on the development of academic management in universities. Lecturers who have achievements will be proud of their universities. So it is necessary to choose the best lecturer.

In selecting the best lecturers at Bhayangkara Jakarta Raya University, there are several factors that become performance assessments, namely the teaching and learning process, questionnaires, student guidance, research and community service[3]. In selecting the best lecturer, computer tools are needed to obtain a decision support system[4] carried out by the decision maker[5].

This study uses the Simple Additive Weighting (SAW) method. The SAW method is used to determine weights and criteria.

\section{RESEARCH METHODOLOGY}

\section{A. Analysis Data}

The basic concept of the SAW method is to find the weighted sum of the performance ratings for each alternative on all attributes. The SAW method requires a decision matrix normalization process $(\mathrm{X})$ to a scale that can be compared with all available alternative ratings. The SAW method requires a decision matrix normalization process (X) to a scale that can be compared with all available alternative ratings.

Fuzzy Multiple Addictive Decision Making (FMADM) is a method used to find optimal alternatives from a number of alternatives with certain criteria[6]. The essence of FMADM is to determine the weight value for each attribute, then proceed with a ranking process that will select the criteria. 


\section{International Journal of Advanced Research in Computer and Communication Engineering}

Vol. 9, Issue 11, November 2020

DOI 10.17148/IJARCCE.2020.91111

The steps in the SAW method are:

1. Make a decision matrix $\mathrm{R}$ measuring $\mathrm{m} \times \mathrm{n}$, where the alternative is selected and $\mathrm{n}=$ criteria.

2. Give each alternative an $X$ value (i) on each criteria (j) which has been determined, for example : $i=1,2, \ldots \mathrm{m}$ dan $\mathrm{j}$ $=1,2, \ldots \mathrm{n}$ on the decision matrix $\mathrm{R}$. as shown in Fig. 1

$$
R=\left[\begin{array}{ccccc}
x_{11} & x_{12} & x_{13} & \ldots & x_{1 n} \\
x_{21} & x_{22} & x_{23} & \ldots & x_{2 n} \\
x_{31} & x_{32} & x_{33} & \ldots & x_{3 n} \\
\ldots & \ldots & \ldots \ldots & \ldots & \ldots \ldots \\
x_{m 1} & x_{m 2} & x_{m 3} & \ldots & \ldots \ldots \\
x_{m n}
\end{array}\right]
$$

Fig. 1 Decision Matrix R

3. The preference weight value $(\mathrm{T})$ is a predetermined criteria

4. normalizing the decision matrix $\mathrm{R}$ by calculating the normalized performance rating (rps) value of the alternatives on the Cs attribute. As the picture shows. 2.

$$
r_{p s}= \begin{cases}\frac{X_{p s}}{M a x_{i} X_{p s}} & \text { If }(s) \text { is the profit attribute } \\ \frac{\operatorname{Min} X_{p s}}{X_{p s}} & \text { If }(s) \text { is the cost attribute }\end{cases}
$$

Fig. 2 calculate the normalized performance rating value

5. Forming a normalized matrix (Z). As shown fig. 3.

$$
\mathrm{Z}=\left(\begin{array}{lllll}
r_{11} & r_{12} & r_{13} & \ldots & r_{1 s} \\
r_{21} & r_{22} & r_{23} & \ldots & r_{2 s} \\
r_{31} & r_{32} & r_{33} & \ldots & r_{3 s} \\
\ldots & \ldots & \ldots & \ldots & \ldots \\
r_{p 1} & r_{p 2} & r_{p 3} & \ldots & r_{p s}
\end{array}\right)
$$

Fig. 3 normalized matrix (Z).

6. Determining the preference value for each alternative $(\mathrm{V})$ by adding the product of the normalized matrix $(\mathrm{Z})$ and the preference value (W). As shown Fig. 4

$$
V_{p}=\sum_{S=1}^{n} w_{s} r_{p s}
$$

Fig. 4 Determining the preference value

\section{B. Application of Simple Addictive Weighted (SAW)}

The stages of application Simple Addictive Weighted are :

1. Weighting To determine the best lecturer, the first stage is to determine the assessment criteria and the weight of each criterion.

2. Determine the value of the matrix to give a decision $\mathrm{R}$ of size $\mathrm{m} \times \mathrm{n}$ obtained from the weighted results.

3. Determining the input score decision matrix then calculating the normalization $(\mathrm{R})$ by using a formula that matches the type of attribute criteria.

4. Calculation of preferences (Vs) can be done when the normalization process has been completed and the results are known. After that all the normalization results are entered into the Preference formula (Vs). 
DOI 10.17148/IJARCCE.2020.91111

\section{RESULTS AND DISCUSSION}

A. Determine the weight of the criteria in determining the best lecturer, we need the weight of the criteria used. as shown in table 1 .

\begin{tabular}{|c|l|c|c|}
\hline Code & \multicolumn{1}{|c|}{ Criteria } & Weight & Explanation \\
\hline C1 & $\begin{array}{l}\text { lecturers have extensive } \\
\text { knowledge }\end{array}$ & 0,4 & Benefit \\
\hline C2 & $\begin{array}{l}\text { Have research and } \\
\text { dedication to task }\end{array}$ & 0,25 & Benefit \\
\hline C3 & $\begin{array}{l}\text { using renewable teaching } \\
\text { methods }\end{array}$ & 0,15 & Benefit \\
\hline C4 & Have competence & 0,1 & Benefit \\
\hline C5 & Share knowledge & 0,1 & \\
\hline & Total & 1 & \\
\hline
\end{tabular}

Table 1. criteria in determining the best lecturer

B. Determine the value of the matrix obtained from the calculation of each criterion. This calculation is the basis for determining the normalized value (R) and the preference value (Vs). the input matrix value can be seen in table 2 .

\begin{tabular}{|l|c|c|c|c|c|}
\hline \multicolumn{1}{|c|}{ Kriteria } & \multicolumn{5}{c|}{ Nama Dosen } \\
\cline { 2 - 6 } & $\mathbf{A 1}$ & $\mathbf{A 2}$ & $\mathbf{A 3}$ & $\mathbf{A 4}$ & $\mathbf{A 5}$ \\
\hline has knowledge of IT technology developments & 91 & 70 & 90 & 80 & 85 \\
\hline always to do Research and Community dedication & 88 & 80 & 85 & 70 & 75 \\
\hline do development in teaching & 86 & 75 & 70 & 80 & 80 \\
\hline have competencies & 84 & 80 & 90 & 90 & 80 \\
\hline share knowledge with colleagues & 84 & 95 & 75 & 95 & 90 \\
\hline
\end{tabular}

Table 2. Input value matrix

The score input in the table above for each of the criteria $\mathrm{C} 1, \mathrm{C} 2, \mathrm{C} 3, \mathrm{C} 4, \mathrm{C} 5$ is already in the form of the initial matrix value. The initial matrix values as shown as in table 3 .

\begin{tabular}{|c|c|c|c|c|c|}
\hline \multirow{2}{*}{ Alternatif } & \multicolumn{5}{|c|}{ Kriteria } \\
\cline { 2 - 6 } & C1 & C2 & C3 & C4 & C5 \\
\hline A1 & 91 & 88 & 86 & 80 & 84 \\
\hline A2 & 70 & 80 & 75 & 90 & 95 \\
\hline A3 & 90 & 85 & 70 & 90 & 75 \\
\hline A4 & 80 & 70 & 80 & 80 & 95 \\
\hline A5 & 85 & 75 & 80 & 90 \\
\hline
\end{tabular}

Table 3 The score of criteria initial matrix

C. Determine the R Matrix (Normalized) to calculation of normalization ( $R$ ) is carried out using a formula that is in accordance with the attribute type of the assessment criteria, because in this case all the attribute criteria are benefit, formula (2) is used. The results of the normalized R matrix. As shown as table 4.

\begin{tabular}{|c|c|c|c|c|c|}
\hline \multirow{2}{*}{ Alternatif } & \multicolumn{5}{|c|}{ Criteria } \\
\cline { 2 - 6 } & $\mathbf{C 1}$ & $\mathbf{C 2}$ & $\mathbf{C 3}$ & $\mathbf{C 4}$ & $\mathbf{C 5}$ \\
\hline $\mathrm{A} 1$ & 1 & 1 & 1 & 0,93 & 0,88 \\
\hline $\mathrm{A} 2$ & 0.76 & 0,9 & 0,87 & 0,88 & 1 \\
\hline $\mathrm{A} 3$ & 0,98 & 0,96 & 0,81 & 1 & 0,78 \\
\hline A4 & 0,87 & 0,79 & 0,93 & 1 & 1 \\
\hline A5 & 0,93 & 0,85 & 0.93 & 0,88 & 0,94 \\
\hline
\end{tabular}

Table 4. results of the normalized R matrix 


\section{International Journal of Advanced Research in Computer and Communication Engineering}

Vol. 9, Issue 11, November 2020

DOI 10.17148/IJARCCE.2020.91111

D. Preference Calculation (Vs) is the result of normalization entered into the Preference formula (Vi), namely formula

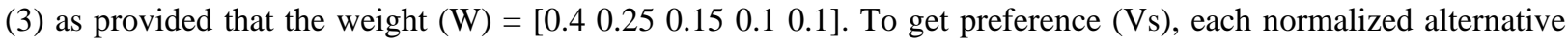
column is multiplied by a predetermined weight. The calculation results are shown in table 5 .

\begin{tabular}{|l|l|}
\hline Alternatif & Nilai Preferensi \\
\hline V5 $=$ A5 & 0,906 \\
\hline V4 $=$ A4 & 0,885 \\
\hline V3 $=$ A3 & 0,9315 \\
\hline V2 $=$ A2 & 0,8475 \\
\hline V1 $=$ A1 & 0,621 \\
\hline
\end{tabular}

Table 5. Preference Calculation

Then the ranking is done so that the results are in table 6.

\begin{tabular}{|l|l|l|}
\hline Alternatif & Nilai Preferensi & Rangking \\
\hline V5 $=$ A5 & 0,906 & 1 \\
\hline V4 = A4 & 0,885 & 2 \\
\hline V3 = A3 & 0,9315 & 3 \\
\hline V2 = A2 & 0,8475 & 4 \\
\hline V1 = A1 & 0,621 & 5 \\
\hline
\end{tabular}

Table 6. The result ranking

From the results of the calculation of preferences that have been ranked, the result is that V5 or A5 has the highest value, and these results can be used as decision support in determining the best lecturer at Bhayangkara University, Jakarta Raya.

\section{E. Design of System}

To design the system with UML (Unified Modelling Language) diagrams which function to model users who interact with the system. Use case diagrams and class diagrams for decision support systems to determine the best lecturers are shown in Figure 5.

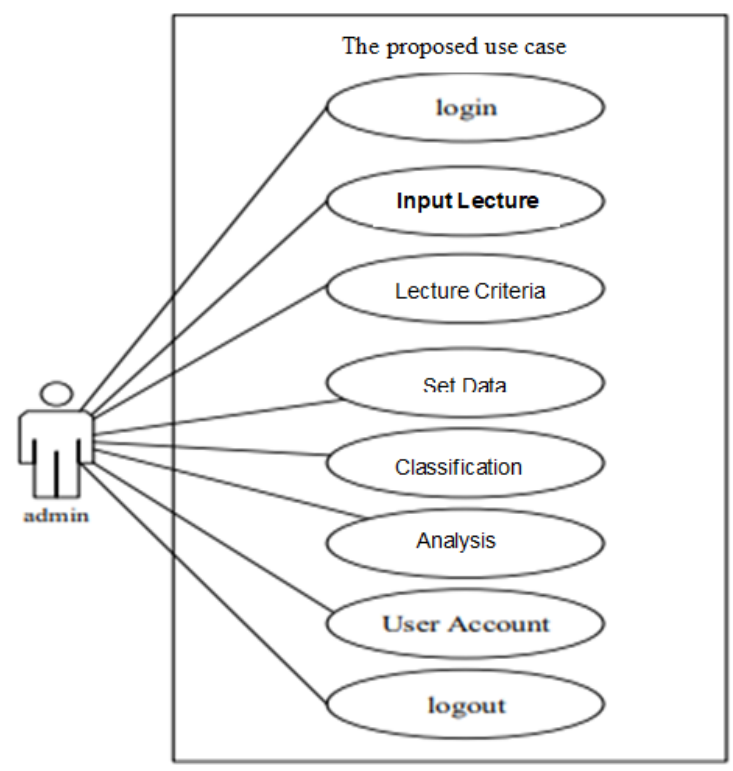

Fig. 5 Use case Diagram 


\section{International Journal of Advanced Research in Computer and Communication Engineering}

Vol. 9, Issue 11, November 2020

DOI 10.17148/IJARCCE.2020.91111

F. Application Design Results

- Main Menu Application is functions as the start page of a system after logging in and as a link between one menu and another. As shown figure 6.

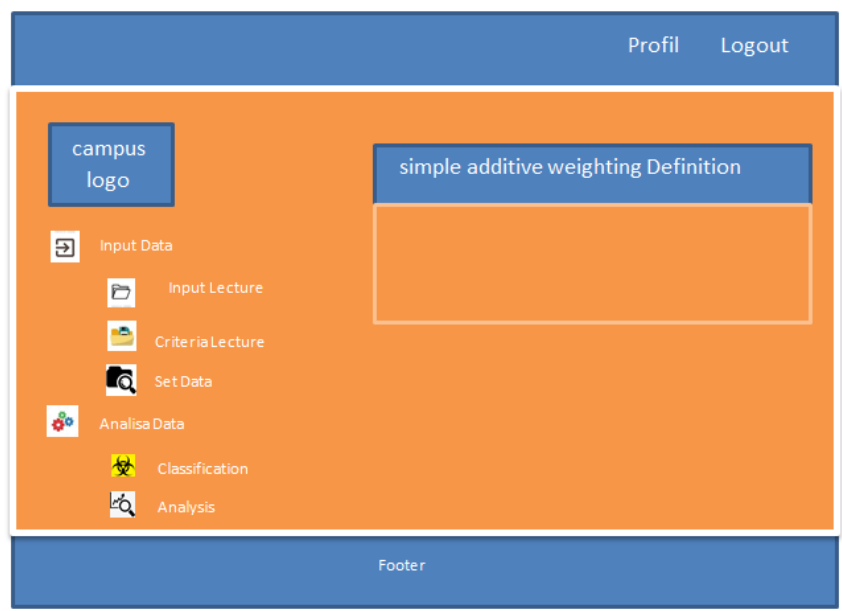

Figure 6. Main menu application

- Lecturer Data Page is functions to see lecturer data and add, change, and delete lecturer data. As shown figure 7.

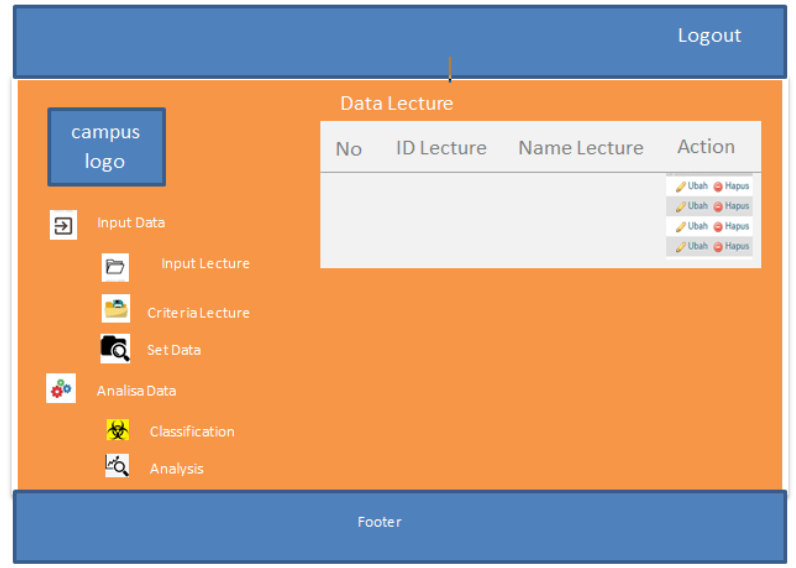

Figure 7. Data Lecture

- The data criteria page functions to view the criteria for lecturer. As shown as figure 8 .

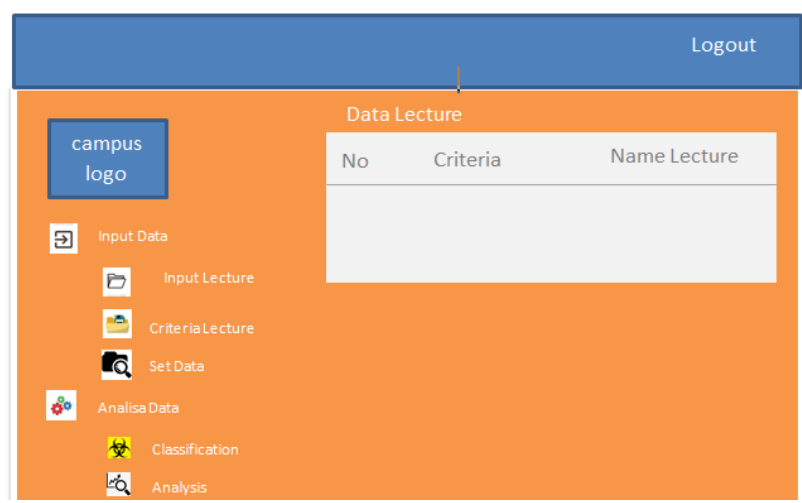

Figure 8. Criteria lecture 


\section{International Journal of Advanced Research in Computer and Communication Engineering}

Vol. 9, Issue 11, November 2020

DOI 10.17148/IJARCCE.2020.91111

\section{CONCLUSION}

Based on the research and discussion, it is possible concluded several things as follows.

- In this research, a support system application has been developed decision support system to determine best lecturers.

- With this decision support system application can help on Bhayangkara Jakarta Raya University work partners to get faster the highest score to determine the best lecturer

- In this Decision Support System application using the Fuzzy SAW (Simple Addictive weighting) to calculate the weight value of the criteria and carry out the process ranking. Where these criteria are given a weighted value and weight value is normalized and then the weight value is calculated and produce the highest ranking.

\section{REFERENCES}

[1] Sofhian, H. Sujaini, and H. S. Pratiwi, "Dosen Terbaik Menggunakan Metode Promethee ( Studi Kasus : Teknik Informatika Universitas Tanjungpura )," J. Sist. dan Teknol. Inf., vol. 1, no. 1, pp. 1-6, 2016.

[2] P. P. Rini, Dedi, and N. Riyanti, "Sistem Pendukung Keputusan Pemilihan Dosen Terbaik Berbasis Web Dengan Metode SAW (Simple Additive Weighting) (Studi Kasus: STMIK Global Tangerang),” Sisfotek Glob., vol. 5, no. 2, p. 9, 2015.

[3] N. Setiawan et al., "Simple additive weighting as decision support system for determining employees salary," Int. J. Eng. Technol., vol. 7, no. 2.14 Special Issue 14, pp. 309-313, 2018.

[4] R. Sistem, "Jurnal Resti," vol. 1, no. 1, pp. 19-25, 2017.

[5] A. Noeman and D. Handayani, "Perancangan Sistem Informasi Document Monitoring Sampling Product Dengan Metode Prototype," vol. 12, no. 3, pp. 219-229, 2019, doi: 10.30998/faktorexacta.v12i3.4678.

[6] E. T. Kersten-van Dijk, J. H. D. M. Westerink, F. Beute, and W. A. IJsselsteijn, "Personal Informatics, Self-Insight, and Behavior Change: A Critical Review of Current Literature," Human-Computer Interact., vol. 32, no. 5-6, pp. 268-296, 2017, doi: $10.1080 / 07370024.2016 .1276456$ 